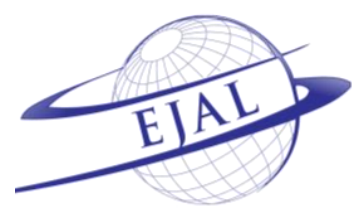

\title{
Challenges of English Language Teaching in High Schools in Turkey and Possible Suggestions to Overcome Them
}

\author{
Aycan Demir Ayaz ${ }^{a}$ (D) , Sinem Ozkardas ${ }^{b}$ (D) , Tuba Ozturan ${ }^{c}$ \\ a Department of Foreign Language Education, Middle East Technical University, Ankara 06800, Turkey \\ $b$ Renison University College, University of Waterloo, Waterloo ON N2K 4E7, Canada \\ c School of Foreign Languages, Erzincan Binali Ylldırım University, Erzincan 24100, Turkey
}

Received 2 January 2018 | Received in revised form 11 November 2018 | Accepted 21 November 2018

\author{
APA Citation: \\ Demir-Ayaz, A., Ozkardas, S. \& Ozturan, T. (2019). Challenges with English language teaching in high schools in \\ Turkey and possible suggestions to overcome them. Eurasian Journal of Applied Linguistics, 5(1), 41-55. Doi: \\ 10.32601/ejal.543778
}

\begin{abstract}
The English language curriculum prepared by the Ministry of National Education for high schools in Turkey seems to be satisfactory in theory, but the related studies about the attitudes of actual practitioners towards English classes in high schools are not detailed and comprehensive enough. This study aims to fill this gap. To do so, qualitative research was conducted with 13 English language teachers and 55 high school students from different parts of Turkey. They were asked for their opinions, applications, observations, and challenges of the English language teaching system in their high schools and some suggestions for the problematic issues were requested from them via open-ended questions. The data were analyzed descriptively; the results showed that most teachers are not satisfied with the coursebooks, crowded classes, quite limited class hours, and unmotivated students. Their main suggestions cover the privatization of education, having language libraries, labs, speaking clubs, and more lesson hours for English and decreasing the number of students in each classroom. Additionally, teachers want to attend international seminars to become aware of the latest methods/sources. Students have some valuable suggestions for the improvements as well. Nearly all of the students are unhappy about the coursebooks; thus, they suggest them to be revised. They also want to join international projects and improve their language skills. As a result of the study, suggestions covering many issues like coursebooks, assessment, teacher training, and European projects were proposed with an aim to diminish the gap between theories and applications in real classes.
\end{abstract}

(C) 2019 EJAL \& the Authors. Published by Eurasian Journal of Applied Linguistics (EJAL). This is an open-access article distributed under the terms and conditions of the Creative Commons Attribution license (CC BY-NC-ND) (http://creativecommons.org/licenses/by-nc-nd/4.0/).

Keywords: High school English classes; challenges; suggestions; attitudes of teachers and students

\section{Introduction}

High school education in Turkey corresponds to the last 4 years of the 12 -year compulsory education $(4+4+4)$. The students who follow the regular steps of national education start high school at the ages of 13 or 14 and graduate when they are 17 or 18. For some high schools that offer a one-year intensive preparatory class to teach a foreign language, the duration of that education rises up to 5 years in total. Turkey, with a large amount of youthful population, has six different types of high schools 
that are Science High Schools, Social Studies High Schools, Anatolian High Schools, Vocational and Technical Anatolian High Schools, Multi-program High Schools, and Religious Vocational High Schools (https://ogm.meb.gov.tr/).

High schools include the 9th to 12 th graders who are selected according to their rank in national exams. The students who are placed in a high school are assumed to be homogenous groups of learners, but with no doubt, they show differences. Especially, their foreign language skills, motivation to learn foreign languages and desire to achieve it differ largely. In order to increase the efficiency of language courses, some measures need to be taken since language education, especially English language education, carries great importance in social, political and economic contexts (Aksoy, Bozdoğan, Akbaş, \& Seferoğlu, 2018). Therefore, the government has made different reforms; the last one was prepared in 2014. This paper aims to analyze the expectations of both language teachers and students in high schools, to define their actual practices compared to the theoretical reforms, and to provide some suggestions following the presentation of the literature review.

\subsection{The $9^{\text {th }}-12^{\text {th }}$ grades English language curriculum}

Based on the social, political and economic needs of the country and the world, English language teaching policies have been revised appropriately for years. In 1997, secondary school students started to take English Language Preparation Program. However, in 2006, the program was banned and then in 2013, compulsory education was adopted as the $4+4+4$ system. According to this system, the students took English language education by starting at the 2nd grade and continued until they finished high school. Based on these reforms, high school English language program was also revised in 2014; however, they did not last for a long time because they could not help the students become global citizens in terms of their language knowledge and usage (Erarslan, 2018). Thus, the English Language Preparation Program was again put into practice in 2017. However, it has been planned to be given at the 5th grade (Aksoy et al., 2018).

The English curriculum that is implemented today in the high schools of Ministry of National Education (MoNE) was prepared in 2014 in parallel to the educational policy of Turkish National Education and No. 1739 of Basic Law of the National Education.

The main objective of the English language curriculum prepared for the 9 th -12 th grades is to make them motivated, efficient and fluent language learners and users (Ministry of National Education Board of Education; MoNE-BoE, 2014). In this regard, the curriculum has been based on the principals of The Common European Framework of Reference for Languages (CEFR). In 2014, some revisions and updates were done for the 2nd - 8th grades; therefore, a revision process became compulsory for the 9 th -12 th grades as well. All of the revisions and updates that were done for the 2nd - 8th and the 9th - 12th grades were mainly for improving the communication skills of the learners. Furthermore, in the 9 th -12 th grades, it was 
aimed to give language skills in an integrative way rather than focusing on each skill separately. Also, the learners were aimed to be autonomous learners by making them aware of the language learning process, both in their mother tongue and in the target language.

While revising the curriculum, the authorities put great emphasis on the activities that trigger collaboration among the learners (MoNE-BoE, 2014); thus, peer and/or group working activities can be found in the coursebooks very often. Moreover, taskbased and project-based activities are involved in the curriculum with an aim to increase the learners' communicative competence, language skills, and autonomy.

Considering all these issues and the CEFR, the Ministry of Education (MoNE) has planned to use coursebooks at different commands in each grade. The 9th graders learn English at A1 and/or A2 level, and their proficiency level gradually increases each year. In the end, it is aimed that the 12 th graders graduate by having knowledge at the B2 level, or sometimes, depending on the opportunity of getting extra one-year intensive language courses (preparatory class), the learners are supposed to graduate with a higher level of language use. In fact, according to the 2nd - 8th grades English curriculum, the students are expected to graduate at A1/ A2 level language command, but when they start high school, they take courses at the same level during the 9th grade. The MoNE gives the reason behind it as the importance of revision and recycling the content of previous years. In addition, it was mentioned in the outline of the latest curriculum prepared at the beginning of the year 2017 that although the students both in secondary schools and in high schools take the same level (A1 and A2), the content of courses differs to a great extent. More clearly, the 9th graders take courses at A1 and A2 level, but with more complex vocabularies and structures compared to the 8th graders. This may make the language learning process complicated and tough as everything is very clear and standard in the CEFR; the curriculum has some points that do not match the principals of the CEFR.

Undoubtedly, English language teachers have specific and vital roles in implementing the curriculum effectively; therefore, they are assumed to have the knowledge of English Language Portfolio (ELP) and use it to assess their target language knowledge as language users. By doing it, the language teachers can become familiar with the principles of the curriculum.

\subsection{Instructional materials}

All the instructional materials that are prepared for the 9th -12 th grades by the MoNE are based on the paradigm that the learners should learn by doing. In this sense, it is suggested in the curriculum that teachers employ Computer-assisted Language Learning (CALL), Mobile-assisted language learning (MALL), and blendedlearning (MoNE-BoE, 2014). Moreover, natural acquisition order has been adopted by the curriculum and each theme and unit has been prepared accordingly.

The Ministry of National Education plans the curriculum, prepares books, publishes and delivers them. Each year the books are given to the students free. Until 
2016, all the grades were taught with the book titled "Yes You Can". It has levels from A1 to B2, and apart from the student's book, a supplementary book is given to the students for self-practice, which helps and guides the students to revise and practice related topics outside the classes. Moreover, the MoNE has some books that have been specifically prepared for vocational high schools. There are three books for three departments: accounting and finance, office management and information and communication technology.

\subsection{Assessment of English in high schools}

Assessment in the new 9 th - 12th-grade curriculum has been designed by MoNE to represent the real-life use of language that is dynamic, communicative, and highly interactive. Therefore, a combination of alternative, electronic, and traditional types of assessment that also reflect the teaching processes in class is planned to be used. According to the curriculum, listening and speaking skills can be assessed during discussion times and by using video blogs. To evaluate all four skills together in an integrated way, the language teachers can use Tech Pack that is an online supplementary material provider, E-portfolios that include every kind of work or project produced by the learner, and traditional pen-and-paper exams. The levels of the tests have been specified in the program in line with the CEFR. Thus, the 9th graders have A1 and A2 levels of the tests, the 10th graders are assessed in $\mathrm{A} 2+$ and B1 levels, the 11th graders are planned to reach the B2 level at the end of the year and are assessed in accordance with it, and finally, the 12th graders have the B2+ level of tests. Since the MoNE does not suggest a standardized testing pack for the teachers, they are totally free while deciding on the content of these assessment tools. The curriculum also talks about different sources of feedback for the assessment. Similar to using various types of assessment, feedback is also planned to be in multiple ways, so it can lead to more permanent learning.

Although the curriculum requires using multiple forms of assessment and feedback via different channels, there is a need for research on the real-life applications of them in the schools of the MoNE. Because of various challenges such as unavailability of some resources (i.e. computers and internet connection to be able to use Tech Pack or E-Portfolio), or highly populated classes, reality may be very different from what is intended in the curriculum.

\subsection{Teacher training}

Teacher training processes are handled under two sub-sections: pre-service and inservice, referring to their formats and challenges. Pre-service teacher training is offered by the Faculties of Education of universities and it has been standardized by the Higher Education Council. These programs consist of both theoretical and practical courses in the area. To provide the theoretical information, methodology courses are offered, and then practical courses such as School Experience and Practice Teaching follow them. Although the flow of the program is quite reasonable, it is not 
free of challenges. During the school experience courses, student-teachers visit language classes to observe their lessons, and for practice teaching courses, they need to teach some classes themselves. While some faculties give them the chance of visiting more than one level of classes to see different teachers and/or school settings, some others send the student-teachers to only one class in the same school taught by the same teacher. The study conducted with the $4^{\text {th }}$-grade practicum students by Seferoğlu (2006) revealed that student-teachers wish to visit as many different teachers, classes, and school settings as possible to familiarize themselves with various situations. They state that visiting the same environment causes demotivation for them. In addition, according to these participants of the study, the balance of theoretical and practical courses in their program is not well-established and they are not happy with overloaded theoretical courses some of which do not help with the practice. Moreover, they complain about visiting their schools only once a week, which hinders the continuity of their observations, and therefore not adequate for them. Student-teachers also think that they do not have enough real life like teaching experience to feel comfortable after graduation (Erten, 2015). Therefore, it is crucial to provide them with longer periods of teaching which are practiced in environments similar to real life. Despite various problems of the practical courses, according to Seferoğlu (2006) and Kömür (2010), the students consider these experiences as the most significant parts of their pre-service education.

In-service teacher training is provided by MONE to the teachers who are already teaching. The aim of that practice is to improve their knowledge and skills in the profession besides adapting them to the advancements in the area (Bozkurt, Kavak, Yamak, Canbazoğlu-Bilici, Darici, \& Ozkaya, 2012). Main themes on which the inservice training is to focus are how to teach English communicatively, studentcentered classes, teachers' guidance and so on; however, the training is lack of them (Kırkgöz, 2009). According to Bozkurt et al. (2012), who investigated secondary school teachers' opinions about in-service training programs, although the teachers are quite positive about the importance of the training, they are not contented with the implementations. The participant teachers mention that inadequate amounts of training, unqualified trainers, unavailability of specific information regarding classroom practices, and poorly designed programs that lack needs analysis are the main reasons for their dissatisfaction. Since the pieces of training are mostly focused on theoretical information, majority of teachers cannot use this information in their classes because of the population, time constraints stemming from heavily loaded curriculums, lack of materials and tools, low proficiency levels of their students, classroom culture in Turkey, and management issues (Uysal, 2012). Therefore, the teachers want in-service training courses to be designed after conducting a wellplanned needs analysis. Uysal (2012) also reveals that the courses are mostly trainercentered and do not provide an environment for the teachers to discuss their problems and find solutions together. Moreover, professional teacher trainers do not design them, but the MONE assigns some teachers working at schools that are more prestigious with the task of organizing these courses and presenting them, which also 
leads to many challenges. To conclude, it is certain that in-service training is highly crucial for the teachers for their professional development (Gültekin \& Çubukçu, 2008), and therefore the training should be planned in advance by professional trainers after conducting the needs analysis for the specific teacher group they will work with.

Based on the literature described so far, this study aims to answer the following research questions:

1. What are the attitudes and opinions of English language teachers teaching in high schools on English language education in Turkey?

2. What are the attitudes and opinions of students studying in high schools in English language education in Turkey?

\section{Method}

\subsection{The aim of the study}

The objective of the study is to explore the ideas about English lessons and attitudes of English language teachers and students towards these courses in high schools in Turkey.

\subsection{Participants}

The study included 13 high school teachers (teaching at the 9th - 12th grades) working in different types of institutions in different parts of Turkey and 55 high school students from different cities and various types of high schools all around Turkey. Convenience sampling was used to choose these participants.

The teachers who participated in that research study had different years of teaching experience ranging from 1.5 to 16 years. Thus, both experienced and less experienced teachers contributed to the findings with different perspectives.

6 of the participant teachers in the study were working at Anatolian High Schools. The number of the Vocational High School teachers was 4, while equal numbers of teachers from High School of Fine Art, Multi-Program High Schools, and Medical Career High School (1 from each school) participated in the study. High school teachers from different regions and cities of Turkey were included in that research. The highest percentage of participants taught in Ağrı (30.7\%) followed by Giresun (23\%). There were also teachers who worked in Kastamonu, Kahramanmaraş, Erzincan, Sivas, and Ankara.

The student participants of the study were also from various types of high schools. The highest percentage of student participants were from Anatolian High Schools and Vocational High School students followed them. High School of Fine Arts, Science High School, Social Sciences High School, and Multi-Program High School students were also available in the study. 
As for the cities of the student participants, while big numbers of them studied in Kastamonu and Erzincan, there were many from Giresun, Bursa, Ağrı, and Ankara as well. Small numbers of student participants from Rize, Bartın, and Mersin were also included in the study.

\subsection{Instruments and data collection}

The data were collected by using two questionnaires with open-ended questions prepared separately for high school teachers and students by the researchers. The questionnaires aimed to elicit data on participants' demographic information, and their ideas and attitudes towards English language teaching and learning at high schools in Turkey. More specifically, the questions asked to the teachers were mainly about their teaching experience, the type of the high schools they worked at, the city they worked in, their ideas about coursebooks and syllabus, attitudes of students towards English lessons, and their suggestions about how to improve the quality of English language teaching at high schools in Turkey. The questionnaire which was conducted with 55 high school students from different cities contained the questions about the cities where they studied, the types of the high schools they studied, their ideas about coursebooks and materials, the attitudes of their English language teachers, their suggestions about English courses, the language skills which were important for them, attending international projects, whether learning English was important for them, and whether they wish they had prep year at high school. They were prepared using Google forms and conducted online.

Data were collected qualitatively and it was analyzed using descriptive analysis. The language of the questionnaires was Turkish, L1 of the participants and their answers were translated into English by the researchers to be reported in the findings section.

\section{Results}

\subsection{Findings regarding English language teachers at high schools in Turkey}

Findings regarding the coursebooks and sources used in lessons showed that only 2 of the teachers seemed happy about the coursebooks while 11 of them were unhappy mainly because of unequal sharing of skills in the books. In addition, the teachers explained that there were some listening parts in the coursebooks, but there were not any CDs or online platforms to access these records, so they had no chance to make their students practice listening exercises. Although they appreciated the communication-focused parts of the books, there were not enough parts about structure teaching or practices.

The question about the attitudes of the students towards English lessons indicated that high school teachers mainly complained about very crowded classrooms and unmotivated students. For example, participant teacher 3 (PT 3) explained the situation with these words: 
"I am very unhappy with my classes because the classrooms are very crowded and the number of courses for each classroom is not enough. It is nearly impossible to create an interactive learning environment for the students".

Only 2 of the teachers were content with their students' attitudes toward learning the English language, and another teacher (PT 7) stated that they had positive attitudes only toward learning grammar:

"My students are not good at language skills, but when we practice grammar, they are fairly good at."

The suggestions of the teachers who joined the study to improve the quality of English language teaching at high schools cover many topics. First of all, some teachers supported privatization of education, providing language libraries and labs for each high school, having speaking clubs or production-based activities and increasing the number of hours for English classes.

"Each and every school should have language libraries and labs. Also, the number of weekly English language courses should be increased. And in these courses, materials with full of activities that trigger language use in four skills should be utilized." (PT 5)

In addition to the increase in the number of courses, a decrease in the number of students in each classroom was seen as a must by the teachers. And they emphasized the integration of four skills rather than pure grammar teaching. PT 3 gave specific suggestions on this point:

"It is an urgent need to decrease the number of students in each class. I think the maximum limit for each language class should be 20. Then, coursebooks and materials that are based on the integration of four skills and on communicative tasks should be used."

Also, 2 of the teachers thought that prep years of high schools should not have been closed. One of the teachers, PT 10, wishes that the students could learn the basics of English at primary and secondary schools, and so they could practice more production activities at high school.

"I think that during primary and secondary education, English language teaching should be more emphasized and courses should be given in the target language. If we achieve this, the students can improve their communication skills more when they start high schools."

Additionally, PT 13 wanted to attend international seminars to become aware of the latest methods and sources stating that:

"As teachers, we should improve our communication skills in the target language and should be aware of the target culture and the latest language teaching methods. The only way to do this is to attend international seminars, conferences or training. I think the MONE should support us and create opportunities for us."

3 of the teachers underlined the need for students to understand the importance and the reasons for learning English. Finally, most of the teachers said that they had 
smart boards at their schools, but the books were not suitable at all to integrate with those smart boards. For example, PT 11 summarized the situation with these words:

"Although there are smart boards at schools, the coursebooks that the MONE give are not suitable to be used on these boards."

\subsection{Findings regarding students at high schools in Turkey}

The descriptive analysis of the answers showed that 25 students were not contented with the coursebooks that were provided by the government at all because they thought that those books were quite boring, repetitive, and they included many spelling mistakes. 6 students mentioned that their teachers did not want to use those books because of the same reasons. They indicated that they bought some other sources advised by their teachers. Although students liked those sources and found them useful, they thought that they were expensive and they never completed the whole book at all. Another challenge was about the $12^{\text {th }}$-grade students who were about to take the National University Entrance Exam. Most of the English teachers who taught the $12^{\text {th }}$ graders let them study for other courses such as mathematics or science during English classes because they were not going to be tested with their English knowledge for the university entrance exam.

Findings revealed that 17 of the students seemed unhappy about the curriculum of English lessons. Even the students who were quite successful in international exams mentioned that they could not speak that language fluently and they did not feel comfortable about production activities. They attributed their feeling of incompetence in learning and speaking English to the language teaching system and curriculum in the country. They found the system quite problematic stating that there was not any development in their English level since primary school. While 11 students thought that their English language teachers were quite unmotivated to teach the language, 14 of the students were pleased with their language teachers and they thought that the teachers were quite knowledgeable and enthusiastic about their job.

The question about the prep year intensive language education indicated that 2 of the participants had already studied prep year at high school and they thought it was quite beneficial for them. 31 of the participants would prefer to study in a prep-class during their high school education so that they could improve their language skills.

The students were also asked their opinion about which language skill carried importance for them and most of them mentioned that they wanted to understand the spoken language and to interact with the people through the target language. However, the students could not practice listening and speaking skills enough in the classroom; rather, they generally focused on grammar, vocabulary, and reading, with which the students did not seem to be satisfied.

The investigation of assessment procedures revealed that 34 participants were not pleased with their language exams. They complained about being tested only for grammar, and they wanted to be tested from speaking and listening, too. However, 
the ones tested from listening mention that they did not do enough listening practices during the lessons and their teachers spoke only in Turkish. The only thing wanted from them was to memorize their notes taken during the lessons, and they seemed to have great difficulty in understanding the instructions. While 15 students did not have any negative feedback about the assessment procedures, 6 students stated that with some changes they would be more effective.

According to the results, only 2 students had international projects at their schools, and they underlined that they could not join them because of the high prices needed for such activities. However, all the participants (except the one who thinks Turkey is the best and enough for him/her) want to join international projects and see other countries so that they can improve their language skills.

The question about their ideas about the importance of English language showed many pleasant results. All of the participants think that English is vital for today's world. Their reasons are mainly it's being the world's common language, expanding their general culture, searching information from different sources, traveling more safely and confidently, having international friends, becoming more successful and prestigious, and having more job opportunities.

Finally, the question asking for suggestions from the students revealed many useful ideas which may help to improve the language education in Turkey. For example, most of the students stated that they wanted to speak in English and they believed that if they were able to speak the language, it would be more meaningful for them. Therefore, during the national exams, they wanted to be tested with speaking skill as well. Participant student 4 (PS 4) summarized it as follows:

"We only learn grammar rules; however, we cannot speak any word in English. I want to communicate in English, understand foreign movies and listen to foreign songs. If I do this, it will be more meaningful for me to learn English."

Some of them mentioned that they wanted to study preparatory class at high school with national and international teachers.

"I wish we could have a chance to study preparatory class at high school as it is the only way to improve our language skills. I think taking English courses both from native speaking and non-native speaking teachers in an intensive way will contribute a lot." (PS 21)

2 students thought that English language teaching should start at much earlier ages, 9 of them explained that teachers should use the target language all the time in class, and they need to be much more informed about English language teaching methods. In addition to these, 3 students thought that schools and teachers should explain the importance of English and motivate students to choose language departments at high schools. 4 participants wanted to watch short movies in English classes to be exposed to authentic language use and to feel more motivated. PS 37 specifically highlighted it: 
"I see many good movies on the internet and I want to watch and understand them in English. However, as our courses are mainly focused on grammar, I cannot do that. I think our teachers can use short movies in classes. Many of us will be motivated in this way."

Lastly, a student supported the idea of making English lessons elective so that only motivated ones would join the lessons and there would not be any disruptive students.

"I am aware of the importance of English today, but not all of my classmates. Therefore, even if I am motivated to learn it, there may be some students in my class who are unmotivated and they disrupt our classes. Therefore, I think language courses should be elective and the students who really want to learn that language should choose the course." (PS 12)

\section{Discussion}

This paper aimed to present the challenges of language education in high schools of Turkey by touching upon the English language teaching curriculum, the coursebooks and the assessment procedure in practice. This research study mainly revealed that, in the Turkish context, there is a discrepancy gap between the language education policies at the macro level and their classroom implications in the micro level, which has been suggested by Kirkgöz (2009) as well. Although everything seems to be satisfactory in theory in the Secondary Education Institutions English Curriculum (9 th $^{\text {- } 12^{\text {th }}}$ Grades) (MEB, 2014; MEB, 2017), when the questionnaires, which were conducted on English language teachers in high schools and the $9^{\text {th }}$ to $12^{\text {th }}$ graders, were analyzed, it was detected that there occurred a gap between practice and theoretical frame.

First of all, it was stated in the related curriculum that the main objective of language education in high schools of Turkey was making the learners motivated, fluent and efficient language learners and users (MEB, 2014). However, the findings of the study revealed that teachers were mainly unsatisfied with the motivational levels of their students. The students also stated that they could not feel as fluent and efficient language users as they only focused on learning grammar. The gap between the objectives of the curriculum and the situation in classroom practice can be attributed to some other challenges reported in the literature and stated by the teachers and the students of the study. For example, coursebook was one of the biggest problem sources in high schools. The 2014 English language teaching program by the MONE focused on the communicative nature of the language more, shifting from grammar-based methods to communicative teaching and that was reflected in the coursebooks as well (Erarslan, 2018). It was declared in the curriculum by the MONE that four skills and language structures were presented in an integrated way in the coursebooks (MEB, 2014). However, teacher participants of the study explained dissatisfaction with the books mainly because of unequal sharing of the skills in them. A great amount of peer and group activities and lack of structure teaching and practice sections in the coursebooks were among the issues to be solved according to 
the teachers. Since the classes in Turkey were highly crowded, it was not realistic to include that many interactive activities that would not work in real classes. Lack of technological equipment for the listening sections of the coursebooks was also a significant challenge for the teachers. Since they could not focus on the communicative sections of the books, they had to work on reading and grammar, and the students felt incompetent about listening and speaking skills. As revealed in that study, the MONE was not successful in designing appropriate materials and delivering them to the users, the reason for which was suggested by Erarslan (2018, p. 341) to be "top-down curriculum design policies of Turkey".

Reasons for low levels of student motivation vary in the literature. According to Kirkgöz (2009) who also handled the issue in the Turkish context, motivational sources of students were mainly instrumental such as getting higher grades and having better job opportunities, while the importance of speaking English in a globalized world to socialize and reach information was discarded by the students. Therefore, students in Turkish school context had limited motivating factors. The effect of learning conditions on learner motivation was also emphasized in studies (Nikolov \& Mijalyevic Djigunovic, 2011; Read, 2003). And besides deficits in terms of language development and content knowledge, these problems also result in psychological disadvantages on the part of the learners such as loss of motivation.

Contrary to the 1997 and 2006 English language teaching programs in Turkey, the 2013 program aimed at moving from traditional pen and paper-based testing of receptive skills to alternative assessment types focusing on productive skills too (Erarslan, 2018). The 2014 high school language program designed in parallel to the principles of 2013 program also had the same purposes; however, the assessment was revealed to lead to a gap between the theory and practice in high schools. Although the MONE theoretically aimed to administer receptive and productive based exams in a semester, they were not done in practice. As reported by the student participants of the current study, tests were based on receptive skills and productive skills were not included in them. Thus, the purpose of learning a language as a tool for communication was discarded.

Teacher education also appeared to be a significant topic to be discussed as a source of the gap between macro and micro levels of high school language education. When the students' expectations and the related literature under this title were analyzed, it can be easily seen that some measures need to be taken. Clearly, as the participant students mentioned, language teachers should also be motivated to teach the language effectively, which can be provided only by effective pre-service and in-service teacher education programs. Around 20 percent of students complained about unmotivated language teachers in their schools. The teachers' lack of motivation may be attributed to their feelings of inability to teach the language as they had more theoretical courses than practical ones (Seferoğlu, 2006) and as they did not have enough real life like teaching experience to feel comfortable after graduation (Erten, 2015). Adding more practical courses to pre-service programs and planning in-service 
training programs after conducting neat needs analysis on the target group could be considered by the faculties of education and the MONE as a possible solution.

As indicated by various studies in Turkish context (Arıkan, 2015; Arslan, 2012; Gursoy, Korkmaz, \& Damar, 2017), improvements on teacher education, instructional methods, curriculum, and language teaching materials were urgently required. Thus, revising the coursebooks, assessment procedures, and teacher education programs could be considered by the MONE. In addition, it is a clear fact that in Turkish state schools, learners are not exposed to adequate language input to prepare them for the globalized world (Aksoy et al., 2018). Thus, although it requires sound planning, increasing the number of class hours for more exposure to L2 and more practice through interactive lessons should be targeted to increase learner achievement and motivation (Aksoy et al., 2018). Finally, having more international projects for both teachers and students may possibly be solutions for increasing the motivational levels of both parties and helping them to be more effective language teachers and learners.

\section{Conclusion}

To conclude, it is highly visible that high schools in Turkey suffer from various challenges regarding the implementation of the curriculum, course materials, testing and assessments procedures in practice, though everything seems to be quite successful in theory. Thus, there is an urgent need to take action to reduce the huge discrepancy between them and increase the quality of language education in Turkish high schools. Rather than top-down policy and program design, the MONE should integrate all stakeholders into that process (Erarslan, 2018). Students and teachers are the two most important parties of the high school education system, and listening to their voices and caring for them should be the starting point for the solutions.

\section{References}

Aksoy, E., Bozdoğan, D., Akbaş, U., \& Seferoğlu, G. (2018). Old wine in a new bottle: Implementation of intensive language program in the 5th grade in Turkey. Eurasian Journal of Applied Linguistics, 4(2), 301-324. doi:10.32601/ejal.464187

Arıkan, A. (2015). An autoethnography of teaching English to young learners: From theory to practice. Anthropologist, 20(1, 2), 77-85.

Arslan, R. Ş. (2012). Bridging the gap between policy and practice in teaching English to young learners: The Turkish context. Pamukkale University Journal of Education, 32(2), 95-100.

Bozkurt, E., Kavak, N., Yamak, H., Bilici, S.C., \& Ozkaya, Y. (2012). Secondary school teachers' opinion about in-service teacher training: A focus group interview study. ProcediaSocial and Behavioral Sciences, 46, 3502-3506.

Erarslan, A. (2018). Strengths and weaknesses of primary school English language teaching programs in Turkey: Issues regarding program components. Eurasian Journal of Applied Linguistics, 4(2), 325-347. doi: 10.32601/ejal.464194

Erten, İ. H. (2015). Listening to practicing teachers: Implications for teacher training programs. Procedia-Social and Behavioral Sciences, 199, 581-588.

Ertopçu, F.B., Inci, H., \& Samur, S. Ö. (2015).Yes You Can. MEB: Ankara. 
Ertopçu, F.B., Inci, H., \&Samur, S. Ö. (2016).Yes You Can. MEB: Ankara.

Gültekin, M., \& Cubukcu, Z. (2008). Perceptions of primary school teachers about in-service training. Journal of Social Sciences, 19, 185-201.

Gursoy, E., Korkmaz, S. C., \& Damar, E. A. (2017). English language teaching within the new educational policy of Turkey: Views of stakeholder. International Education Studies, 10(4), 18-30.

Kırkgöz, Y. (2009). Globalization and language policy in Turkey. Educational Policy, 23(5), 663-684.

Kömür, S. (2010). Teaching knowledge and teacher competencies: A case study of Turkish preservice English teacher. Teaching Education, 21(3), 279-296.

Nikolov, M., \& Mihaljevic Djigunovic, J. (2011). All shades of every colour: An overview of early teaching and learning of foreign languages. Annual Review of Applied Linguistics, 31, 95-119.

Okul Tanıtım Bilgileri (2015, Mayıs). Retrieved from https://ogm.meb.gov.tr/.

Read, C. (2003). Is younger better?, English Teaching Professional, 28, 5-7.

Republic of Turkey Ministry of National Education Board of Education (MoNE-BoE). (2014). Secondary Education Institutions English Curriculum (9th $-12^{\text {th }}$ Grades). Ankara: Republic of Turkey Ministry of National Education.

Republic of Turkey Ministry of National Education Board of Education (MoNE-BoE). (2017). Secondary Education Institutions English Curriculum (9th $-12^{\text {th }}$ Grades) Ankara: Republic of Turkey Ministry of National Education.

Seferoğlu, G. (2006). Teacher candidates' reflections on some components of a pre-service English teacher education programme in Turkey. Journal of Education for Teaching, 32(4), 369-378.

Uysal, H. H. (2012). Evaluation of an in-service training program for primary-school language teachers in Turkey. Australian Journal of teacher education, 37(7): 14-29. doi: 10.14221/ajte.2012v37n7.4.

\section{Appendix A.}

A.1. Attitudes and opinions of English language teachers teaching in high schools on English language education

1. E-mail?

2. Years of experience?

3. What type of high school do you teach at and in which city is your school?

4. What do you think about the language coursebooks and other materials and resources that you use in your classes?

5. What are the things that you like and dislike in your school about English language education and curriculum?

6. How are your students' attitudes towards the English language?

7. What do you think should be done to improve the quality of English language education in high schools?

\section{A.2. Attitudes and opinions of students studying in high schools on English language education}

1. E-mail?

2. What type of high school do you study at and in which city is your school?

3. What do you think about the English language coursebooks and other materials and resources that are used in your classes? 
4. What are the things that you like and dislike in your school about English language education, curriculum?

5. How are your teachers' attitudes towards teaching English?

6. Do you think that compulsory preparatory class education system for high schools (one-year intensive language education) should be practiced? Would you like to study in pre-class?

7. Which skills are more important for you while learning English?

8. Do you think that your English language exams in school test your language knowledge and skills? What kinds of changes would you suggest for the tests?

9. Do you have international projects at your school to go abroad? Would you like to take responsibility for the preparation process of these projects and go abroad?

10. Do you think that speaking English is important? Why?

11. What do you think should be done to improve the quality of English language education in high schools?

\section{Copyrights}

Copyright for this article is retained by the author(s), with first publication rights granted to the Journal.

This is an open-access article distributed under the terms and conditions of the Creative Commons Attribution license (CC BY-NC-ND) (http://creativecommons.org/licenses/by-nc-nd/4.0/). 